\title{
PAGELARAN SENI TARI INDONESIA
}

\author{
Siti Nuryani ${ }^{1)}$, Martin Halim ${ }^{2)}$ \\ 1) Program Studi S1 Arsitektur, Fakultas Teknik, Universitas Tarumanagara, snuryani57@gmail.com \\ 2) Program Studi S1 Arsitektur, Fakultas Teknik, Universitas Tarumanagara, martinhalim90@gmail.com
}

\begin{abstract}
Abstrak
Ketertarikan masyarakat Indonesia terhadap seni dan budaya tradisional saat ini mulai memudar, terutama seni tari tradisional, sebagai contoh Jakarta. Jakarta sebagai daerah tujuan wisata semakin pesat dan meluas, hal yang paling menonjol dari pariwisata Kota Jakarta adalah sejarah dan belanja. Kawasan Senen, Jakarta Pusat merupakan kawasan yang memiliki sejarah melekat tentang Seniman Senen. Namun kondisi Kawasan Senen sudah tidak lagi memberikan ruang untuk para senimannya mengekpresikan dirinya, untuk itulah perlu di buat sebuah ruang yang dapat menampung kegiatan para seniman di kawasan ini. Pagelaran Seni Tari Indonesia yang dirancang di Kawasan Senen, Jakarta Pusat bertujuan untuk mendongkrak dan 'memperkenalkan kembali' tarian tradisional Indonesia kepada masyarakat Indonesia. Dengan mengadakan kembali aktivitas yang hilang 'Pagelaran Seni Tari Indonesia' merupakan sebuah ruang pertunjukan yang menampilkan berbagai macam tarian daerah yang berbeda, yang dilengkapi dengan ruang-ruang pendukung sebagai sarana melestarikan seni tari tradisional dengan menciptakan ruang yang modern namun tidak kehilangan nuansa tradisionalnya, dan dilengkapi dengan rencana penataan ruang terbuka hijau untuk mewadahi program aktivitas kesenian budaya bagi para seniman yang tidak memiliki wadah untuk mengekpresikan dirinya. Adapun yang menjadi target adalah: wisatawan mancanegara/lokal, pengunjung dalam dan luar kota Jakarta, serta masyarakat sekitar. Sehingga dengan dibangunnya Pagelaran Seni Tari Indonesia di kawasan ini diharapkan dapat memunculkan kembali kesenian tradisional ke tengah kota yang sudah mulai melemah kecintaannya terhadap seni tradisional, khususnya di Kawasan Senen yang sudah kehilangan jati dirinya sebagai kawasan seniman.
\end{abstract}

Kata kunci: Sejarah, Senen, Seni Tradisional

\begin{abstract}
Indonesian people's interest in traditional arts and culture is now fading, especially traditional dance, for example Jakarta. Jakarta as a tourist destination is increasingly rapid and widespread, the most prominent thing about Jakarta City tourism is history and shopping. Senen area, Central Jakarta is an area that has an inherent history about Senen Senen. However, the condition of Senen Region no longer provides space for the artists to express themselves, so that a space that can accommodate the activities of artists in the region is needed. The Indonesian Dance Performance designed in the Senen area, Central Jakarta aims to boost and re-introduce Indonesian traditional dances to the people of Indonesia. By holding back the lost activities 'Indonesian Dance Performances' is a performance space that displays a variety of different regional dances, which are equipped with supporting spaces as a means of preserving traditional dance by creating a modern space that does not lose its traditional nuances, and equipped with a plan for green open space to accommodate cultural arts activity programs for artists who do not have a place to express themselves. The targets are: foreign / local tourists, visitors inside and outside Jakarta, and surrounding communities. So that with the construction of the Indonesian Dance Performance in this area, it is expected to bring back traditional art to the center of the city which has begun to weaken its love of traditional art, especially in the Senen area which has lost its identity as an artist area.
\end{abstract}

Keywords: History, Senen, Traditional Art 


\section{PENDAHULUAN}

\section{Latar Belakang}

Perkembangan kebudayaan Indonesia yang semakin maju menjadi salah satu faktor terciptanya beragam kesenian Indonesia khususnya seni tari. Hal ini menjadi pemicu adanya persaingan akan keeksistensiannya dimasyarakat, yang disebabkan oleh kurangnya apresiasi dan minat masyarakat terhadap budaya lokal dibandingkan dengan seni tari modern yang dianggap tidak monoton.

Kurangnya kesadaran masyarakat akan melestarikan warisan budaya dalam seni tari tradisional mengakibatkan seni tari tradisional kurang diapresiasi dan hilang dimakan waktu. Dalam kesenian tradisonal banyak pesan moral yang terkandung didalamnya yang menceriminkan kepribadian bangsa Indonesia, sehingga seni ini perlu di kembangkan dan ditunjukan kepada masyarakat luas khususnya remaja sebagai sarana rekreasi dan pembelajaran.

Oleh karena itu perlu adanya wadah yang dapat melestarikan seni tari tradisional Indonesia. Pagelaran Seni Tari Indonesia ini dapat menjadi media untuk lebih memperkenalkan budaya lokal Indonesia ke lingkup Internasional dan menjadi objek wisata budaya bagi turis mancanegara di Jakarta.

\section{Maksud Proyek}

Bangunan ini merupakan sebuah wadah yang dapat memfasilitasi kegiatan seni tari tradisional dengan penyediaan ruang pertunjukan, pelatihan, serta pameran sebagai penunjang kegiatan tersebut. Dengan dibangunnya proyek ini dapat dijadikan suatu pendorong untuk menghidupkan kembali kesenian tradisional khususnya di kawasan perkotaan.

\section{Tujuan Proyek}

Tujuan proyek adalah merencanakan sebuah wadah untuk menampilkan sebuah kesenian budaya yang dapat melestarikan kebudayaan seni tari tradisional Indonesia, mendukung program pemerintah dalam meningkatkan pariwisata Indonesia, dan memperkenalkan dan menarik minat wisatawan lokal dan mancanegara untuk berwisata ke Indonesia melalui seni pertunjukan tari tradisional.

Tujuan tersebut diharapkan dapat tercapai melalui penyediaan wadah berupa sebuah Gedung Pertunjukan Seni Tradisional yang desainnya berwawasan lingkungan (menerapkan prinsip Green Architecture), yang merupakan ciri arsitektur masa depan

\section{METODE}

Metode yang akan dipilih dalam menyusun pengembangan proyek ini adalah melakukan sebuah "riset eksploratif", penelitian akan mengajukan what untuk menggali informasi lebih jauh. Sehingga dapat memberikan stimulasi akan kelanjutan proyek kedepannya. Langkahlangkah yang akan digunakan adalah melakukan observasi dan studi kasus; menganalisis isu yang ada sehingga menghasilkan fungsi/proyek yang dapat mendukung ataupun mengatasi langsung permasalahan dari isu yang ada; mengelola data yang ada untuk membuat program yang sesuai dalam perancangan; dan menentukan lokasi yang sesuai dengan kebutuhan proyek.

\section{DISKUSI DAN HASIL}

\section{Pengertian Architourism of the Metropolis}

Menurut Jan Spetch, arsitektur memiliki dua peran berbeda dalam pariwisata khususnya di perkotaan, yaitu Arsitektur Wisata atau Tourism Architecture dan Wisata Arsitektur atau Architectural Tourism. Architectural Tourism tidak terbatas pada gaya atau aliran dari periode waktu yang spesifik. Tampilan bentuk (ikonik) menjadi kunci dalam definisi ini. Architectural 
Tourism juga dapat diartikan sebagai obyek (bentuk) atraksi dan pusat pandangan para turis (Specht, 2014)

Secara etimologi, kata metropolitan (kata benda) atau metropolis (kata sifat) berasal dari bahasa Yunani Kuno, yang kata meter berarti ibu, dan kata polis berarti kota, jadi metropolis adalah Ibu Kota. Secara umum, metropolitan juga dapat didefinisikan sebagai pusat pemukiman besar yang terdiri dari kota besar dan beberapa di daerah sekitarnya dengan satu atau lebih kota besar yang berfungsi sebagai penghubung ke kota-kota di sekitarnya (www.ukssays.com, 2018).

\section{Jakarta Sebagai Pusat Budaya}

Dampak dari urbanisasi yang terjadi di Jakarta, menjadikan Jakarta sebagai tempat berkumpulnya beragam suku dan budaya, banyak penduduk desa yang menetap di Jakarta dan berkeluarga sehingga membuat Jakarta terus berkembang dengan beragam suku budayanya.

Indonesia memiliki sejarah yang panjang dan memiliki banyak kekayaan dari alam, kebudayaan hingga seni tradisional yang ada. Indonesia juga memiliki banyak suku yang juga melahirkan berbagai kebudayaan tradisional yang berbeda di setiap daerah yang ada. Perkembangan zaman saat ini memudahkan pengaruh luar yang masuk tidak dapat dihindari. Sebagai negara yang besar, tentu saja Indonesia tidak bisa menutup diri dari negara lain. Berbicara mengenai seni dan budaya tradisional, saat ini ketertarikan masyarakat terhadap kesenian tradisional mulai memudar.

\section{Melestarikan Seni dan Budaya Lokal}

Seni dan kebudayaan lokal merupakan aset yang berharga jika diolah dengan baik. Sebagai contoh kebudayaan dan kesenian Korea masih tetap eksis meskipun banyak pengaruh dari negara asing. Kebudayaan Indonesia dan keseniannya juga telah memiliki penggemarnya sendiri sebenarnya memiliki potensi yang sama seperti Negara Korea dan Negara lainnya.

Pertunjukkan seni dan kebudayaan lokal memang perlu dilakukan secara rutin sehingga dapat memperkenalkannya kepada generasi saat ini. Untuk mengapresiasi dan melestarikan seni dan budaya Tradisional Indonesia dengan cara membuat sebuah pusat pertunjukan seni, segaligus dapat mewadahi dan mengekspresikan ke kreatifitasan anak bangsa.

\section{Tinjauan Lokasi Proyek}

Lokasi yang diamati Kec. Senen, Jakarta Pusat dikarenakan adanya pemusatan kawasan budaya dan perekonomian. Hal ini sangat memenuhi kriteria pemilihan lokasi. Dalam sejarahnya kawasan Senen pada tahun 1942 hingga 1950-an menjadi tempat favorit berkumpulnya para seniman dari seantero Nusantara (jakartac.o.id, 2018). Namun dengan seiring waktu pusat kesenian berpindah ke kawasan cikini, sehingga kawasan Senen kehilangan jati dirinya sebagai kawasan Seniman. Lokasi tapak berada di Jalan Keramat Raya, Kcamatan Senen, Kelurahan Kramat Jakarta Pusat. Luas tapak 5000 m2.
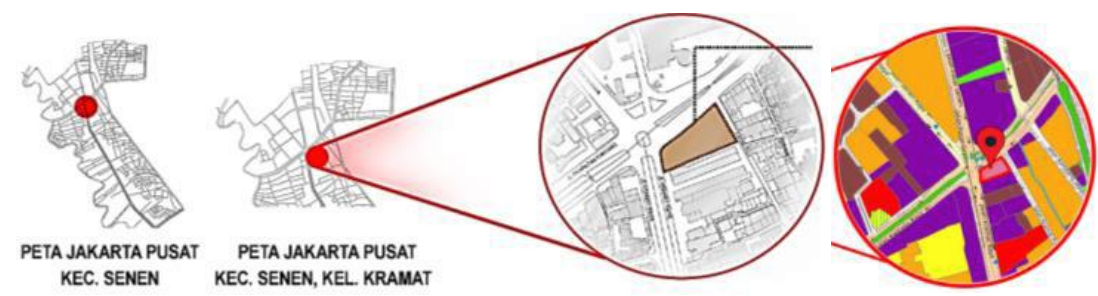

Gambar 1 : Lokasi Tapak

Sumber : Dokumen Pribadi

Tapak merupakan lahan gedung bioskop tua Grand Theater yang sudah tidak beroperasi lagi. 


\section{Pengaruh Perancangan Terhadap Sekitar Tapak}

Proyek ini menyediakan obyek wisata sebagai sarana pembelajaran dan hiburan yang menjadi fasilitas pendukung di kawasan yang berdekatan dengan area komeresial, yang akan menjadikan hubungan timbal balik yang saling berkesinambungan. Mendukung kegiatan wisata di lokasi ini dan membantu mewujudkan rencana pemerintah yang salah satunya adalah untuk meningkatkan kegiatan pariwisata sebagai penambahan devisa Negara. Menambah sebuah ikon di kawasan senen yang mulai menghilang ikonya sebagai kawasan seniman, itu terbukti dengan terbengkalainya bioskop grand theater yang merupakan bioskop tertua di Jakarta setelah Metropol XXI di Cikini.

\section{Konsep Perancangan}

Program Kegiatan

Tabel 1: Tabel Program Kegiatan

\begin{tabular}{|c|c|c|c|}
\hline No & Aktivitas/Kegiatan & Jenis Kegiatân & Keterangan \\
\hline 1 & $\begin{array}{l}\text { Pertunjukan (Indoor } \\
\text { \& Outdoor) }\end{array}$ & Utama & $\begin{array}{l}\text { Penyajian kegiatan informasi berupa : } \\
\text { - Tarian } \\
\text { Penyajian ruangan berupa : } \\
\text { - Permainan cahaya }\end{array}$ \\
\hline 2 & $\begin{array}{l}\text { Pameran Pakaīan } \\
\text { Adat }\end{array}$ & Utama & $\begin{array}{l}\text { Penyajian kegiatan informasi berupa : } \\
\text { - Mannequin pakaian tari } \\
\text { tradisional } \\
\text { - Layar înteraktif }\end{array}$ \\
\hline 3 & Pelatihan Seni Tari & Utama & $\begin{array}{l}\text { Mempelajari gerakan seni tari } \\
\text { tradisional. }\end{array}$ \\
\hline 4 & Ruang Introduction & Utama & $\begin{array}{l}\text { Penyajian ruangan berupa : } \\
\text { - Sebuah ruang yang menceritakan } \\
\text { sejarah tarian } \\
\text { - } \quad \text { Permainan pencahayaan yang } \\
\text { menunjukkan perasaan penari } \\
\text { - Sebuah layar yang menceritakan } \\
\quad \text { alur sejarah tersebut }\end{array}$ \\
\hline 5 & Ruang Simulator & Utama & $\begin{array}{l}\text { Penyajian ruang berupa : } \\
\text { - Ruang pembelajaran secara } \\
\text { digital }\end{array}$ \\
\hline 5 & $\begin{array}{l}\text { Cafetarian \& } \\
\text { Souvenir Shop }\end{array}$ & Pendukung & Kegiatan îstirahat dan berbelanja \\
\hline 6 & Ruang Foto & Pendukung & $\begin{array}{l}\text { Penyajian ruangan berupa : } \\
\text { - } \quad \text { Photo Booth } \\
\text { - Layar LCD touch screen }\end{array}$ \\
\hline
\end{tabular}

Sumber: dokumen pribadi

Kebutuhan luasan total bangunan Pagelaran Seni Tari Indonesia, sebagai berikut :

Tabel 2: Perhitungan Luasan

\begin{tabular}{|l|c|}
\hline \multicolumn{1}{|c|}{ Kegiatan } & Luas \\
\hline Failitas Utama & $2.760 \mathrm{~m}^{2}$ \\
\hline Fasilitas Pendukung & $796 \mathrm{~m}^{2}$ \\
\hline Fasilitas Penunjang & $867 \mathrm{~m}^{2}$ \\
\hline Jumlah Luas & $4.423 \mathrm{~m}^{2}$ \\
\hline Sirkulasi & $30 \%$ \\
\hline Luas Total & $5.750 \mathrm{~m}^{2}$ \\
\hline Basement & $2.700 \mathrm{~m}^{2}$ \\
\hline
\end{tabular}

Sumber: dokumen pribadi

\section{Konsep Rancangan Proyek}

Konsep bentuk perancangan bangunan menginterpretasikan kebudayaan, kebudayaan selalu berputar turun-temurun dari generasi kegenerasi dan tak pernah terputus. 


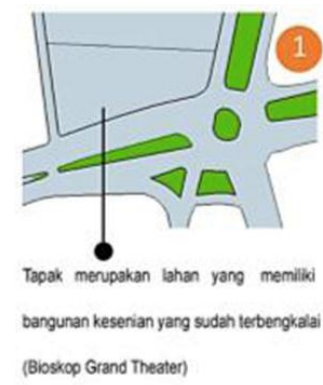

Gambar 2. Konsep Perancangan Massa Bangunan Sumber: Dokumen Pribadi

Lokasi proyek ini berada di jalan utama yang merupakan titik penting dalm penglihatan pengguna jalan. Pemberiaan bukaan didepan jalan utama sangat penting untuk menarik pengunjung.
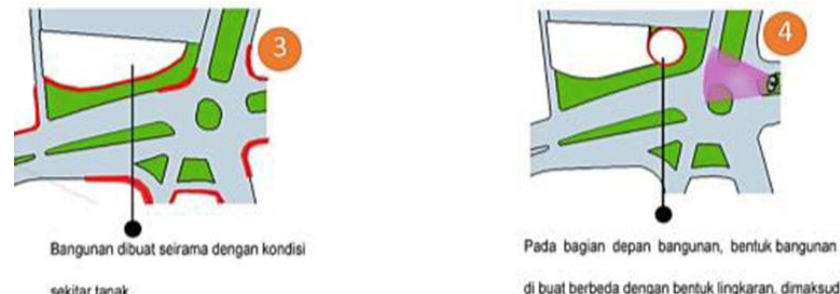

untuk membuat orang yeng meleat tapak ini, merasa

penasaran, dan menarik pengunjung lannya

Gambar 3. Konsep Perancangan Massa Bangunan Sumber: Dokumen Pribadi

Pembentukkan dasar massa bangunan mengikuti bentuk tapak, untuk menyelaraskan dengan lingkungan sekitar tapak, maka pada sisi-sisi bangunan di buat melengkung.
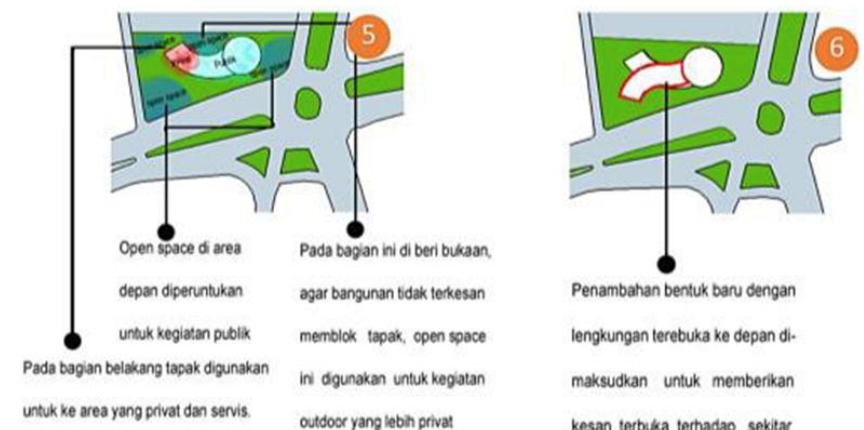

kesan terbuka terhadap sektar

tapak.

Gambar 4. Konsep Perancangan Massa Bangunan

Sumber: Dokumen Pribadi

Ruang terbuka hijau yang terdapat pada bangunan dapat digunakan sebagai aktivitas publik yang dapat membaur dengan aktivitas di sekitar tapak. Tampak depan bangunan sebagai entrance digunakan sebagai akses jalur kendaraan, pejalan kaki, bagian samping kanan bangunan digunakan sebagai area servis dan parkir kendaraan (sepeda motor). 


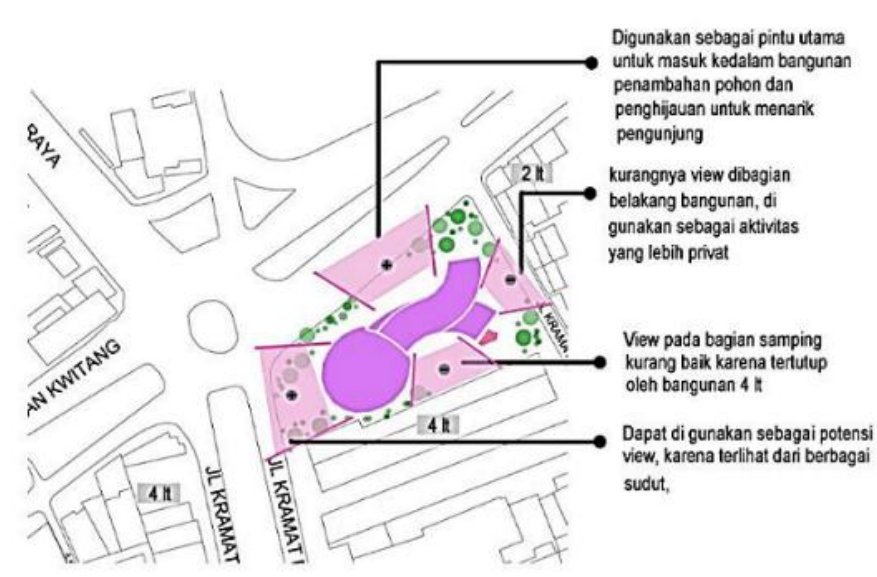

Gambar 5. Analisa View

Sumber: Dokumen Pribadi

Jalur utama entrance pada bangunan ini berada di sisi-sisi utara tapak, berbatasan langsung dengan jalan arteri primer sebagai akses utama. Sedangkan jalur side entrance berada di Timur dan Barat tapak, pada bangian Timur tapak di gunakan untuk akses masuk sepeda motor dan keluar mobil dari basement dan pada bagian Barat Tapak digunakan untuk masuk kedalam basement dan keluar mobil

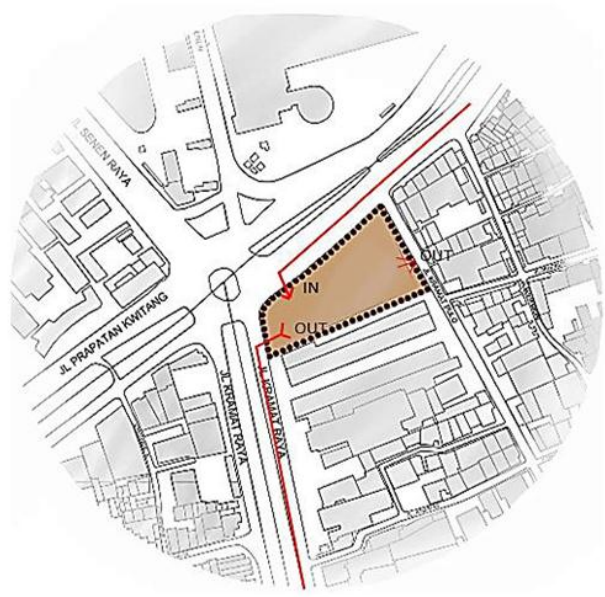

Gambar 6. Analisa Aksesibilitas

Sumber: Dokumen Pribadi

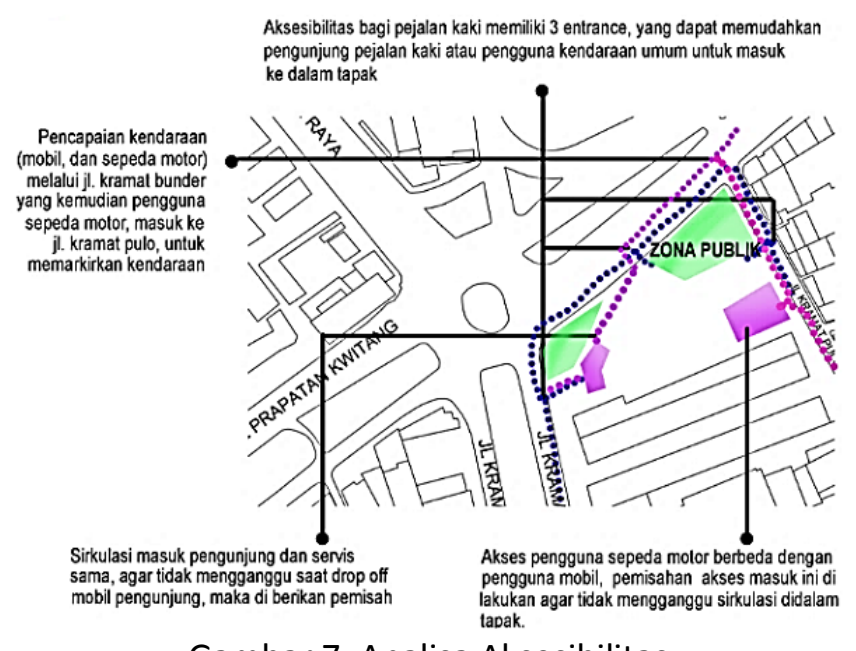

Gambar 7. Analisa Aksesibilitas

Sumber: Dokumen Pribadi 


\section{Zoning Massa Bangunan}

Zoning disusun berdasarkan pembagian program yang telah disusun berdasarkan kebutuhan publik dan privat, dimana kebutuhan publik di letakkan dibagian yang mudah dicapai pengunjung.

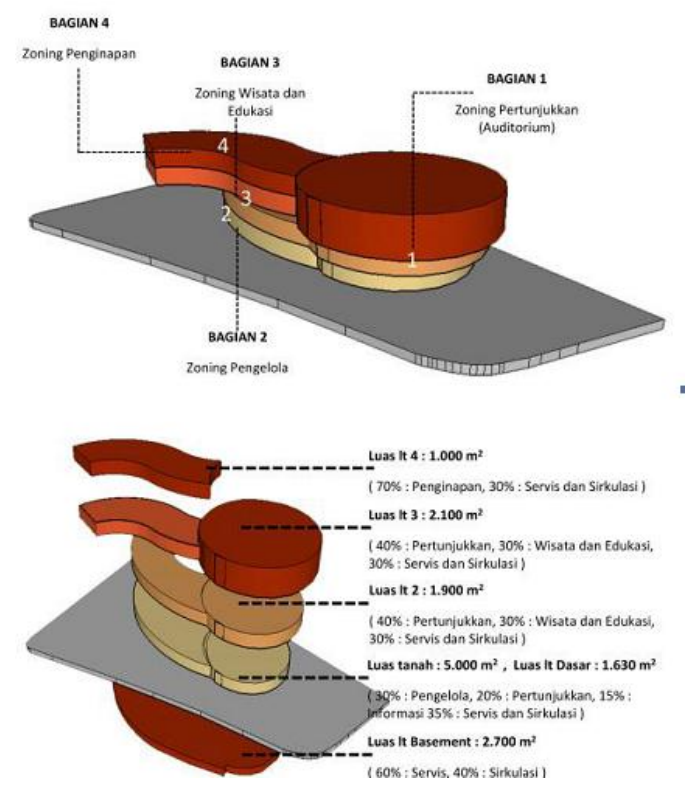

Gambar 8. Zoning

Sumber: Dokumen Pribadi

\section{Hasil Rancangan Proyek}

Pagelaran Seni Tari Indonesia merupakan proyek Tugas Akhir yang diharapkan dapat menjadi sarana untuk mewadahi kegiatan seni di kawasan Senen. Wadah ini sekaligus dapat menjadi tujuan wisata yang baru dikawasn Senen.

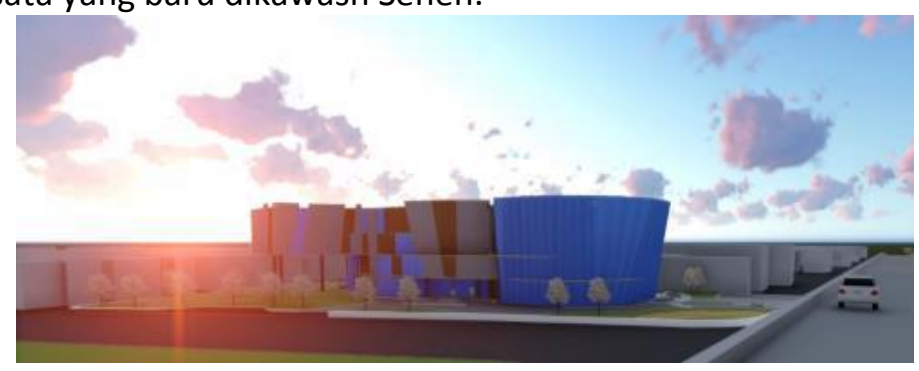

Gambar 9. 3d Eksterior Pagelaran Seni Tari Indonesia Sumber : Dokumen Pribadi

Lokasi : Jl. Keramat Raya, Kcamatan Senen, Kelurahan Kramat Jakarta Pusat Luas bangunan : $5.750 \mathrm{~m} 2$

Fungsi Lahan : Zona Perdagangan \& Jasa

Luas Lahan : $5.000 \mathrm{~m}^{2}$

KDB (60\%): $3.000 \mathrm{~m}^{2}$

$\mathrm{KB}: 8$

$\operatorname{KLB}(3.5): 17.500 \mathrm{~m}^{2}$

KTB (55\%) : $2.750 \mathrm{~m}^{2}$

$\mathrm{KDH}(30 \%): 1.500 \mathrm{~m}^{2}$

Berdasarkan hasil analisis data dan konsep perancangan proyek terhadap zona tapak dan massa bangunan diperoleh desain perancangan proyek sebagai berikut : 


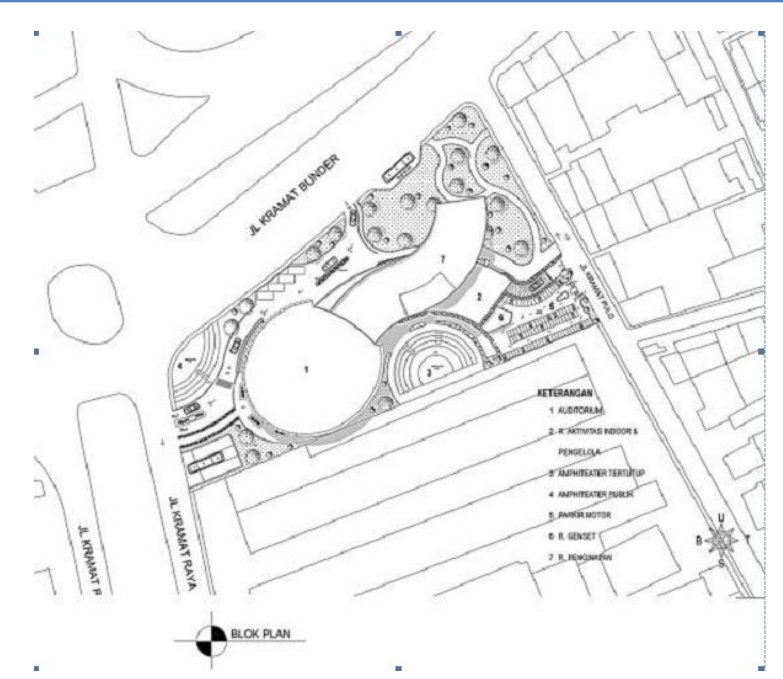

Gambar 10. Blok Plan

Sumber: Dokumen Pribadi
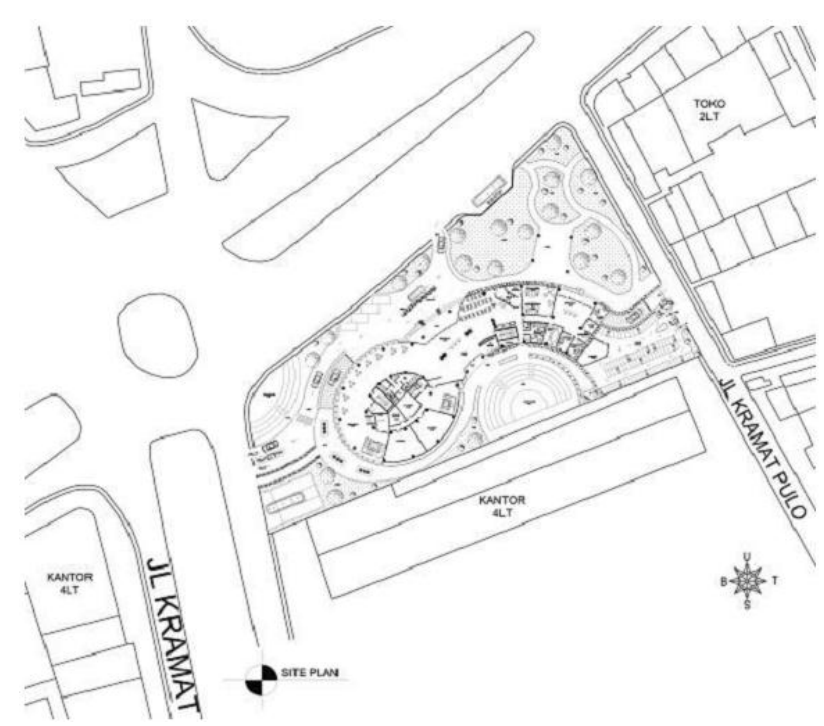

Gambar 11. Site Plane

Sumber: Dokumen Pribadi

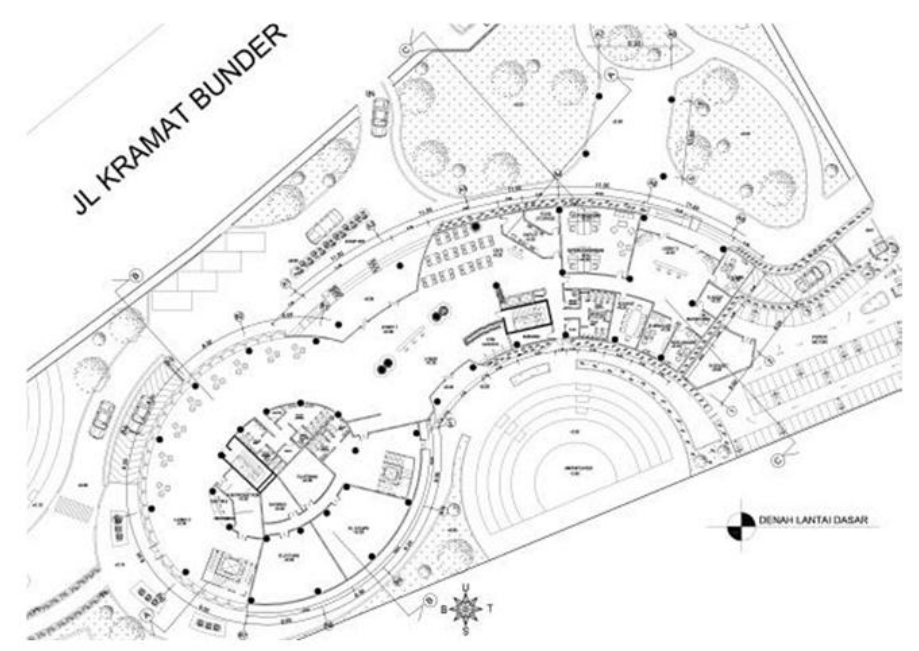

Gambar 12. Denah Lantai Dasar

Sumber: Dokumen Pribadi 


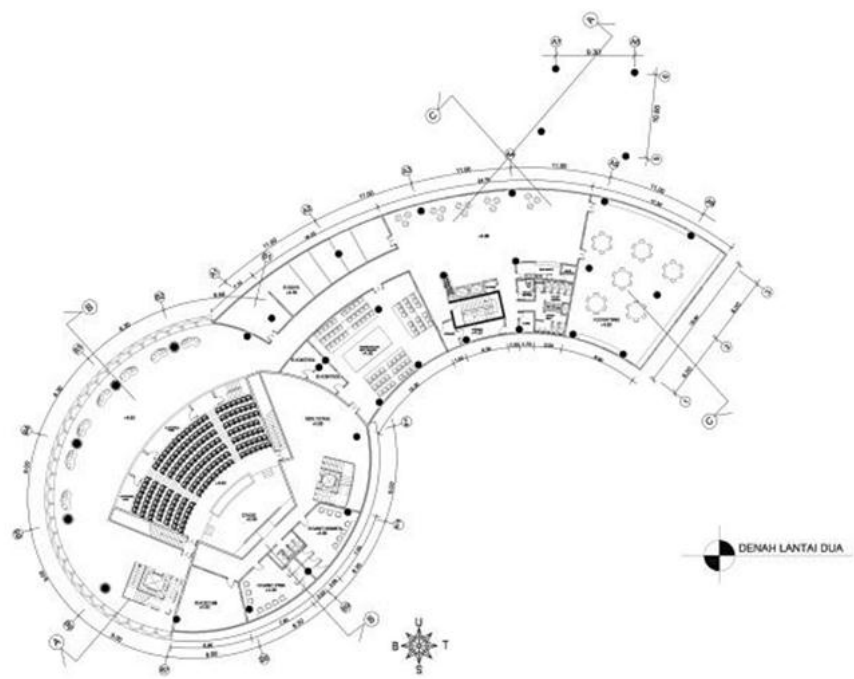

Gambar 13. Denah Lantai Dua

Sumber: Dokumen Pribadi
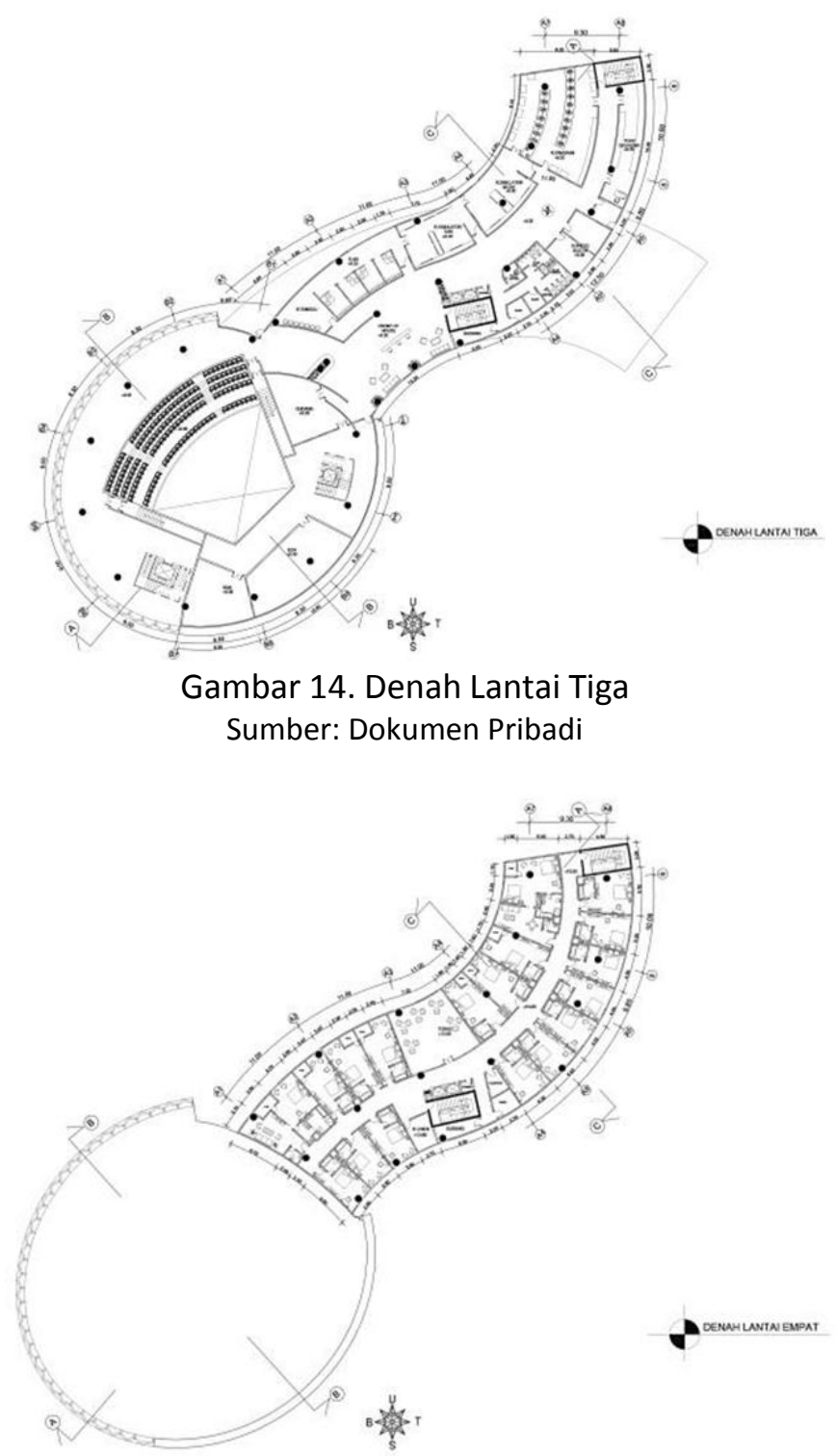

Gambar 15. Denah Lantai Empat

Sumber: Dokumen Pribadi 


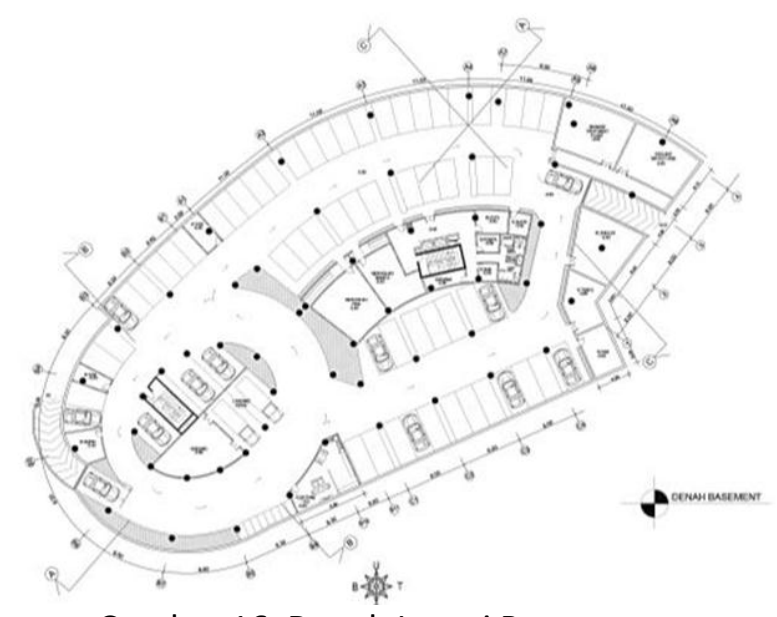

Gambar 16. Denah Lantai Basement Sumber: Dokumen Pribadi
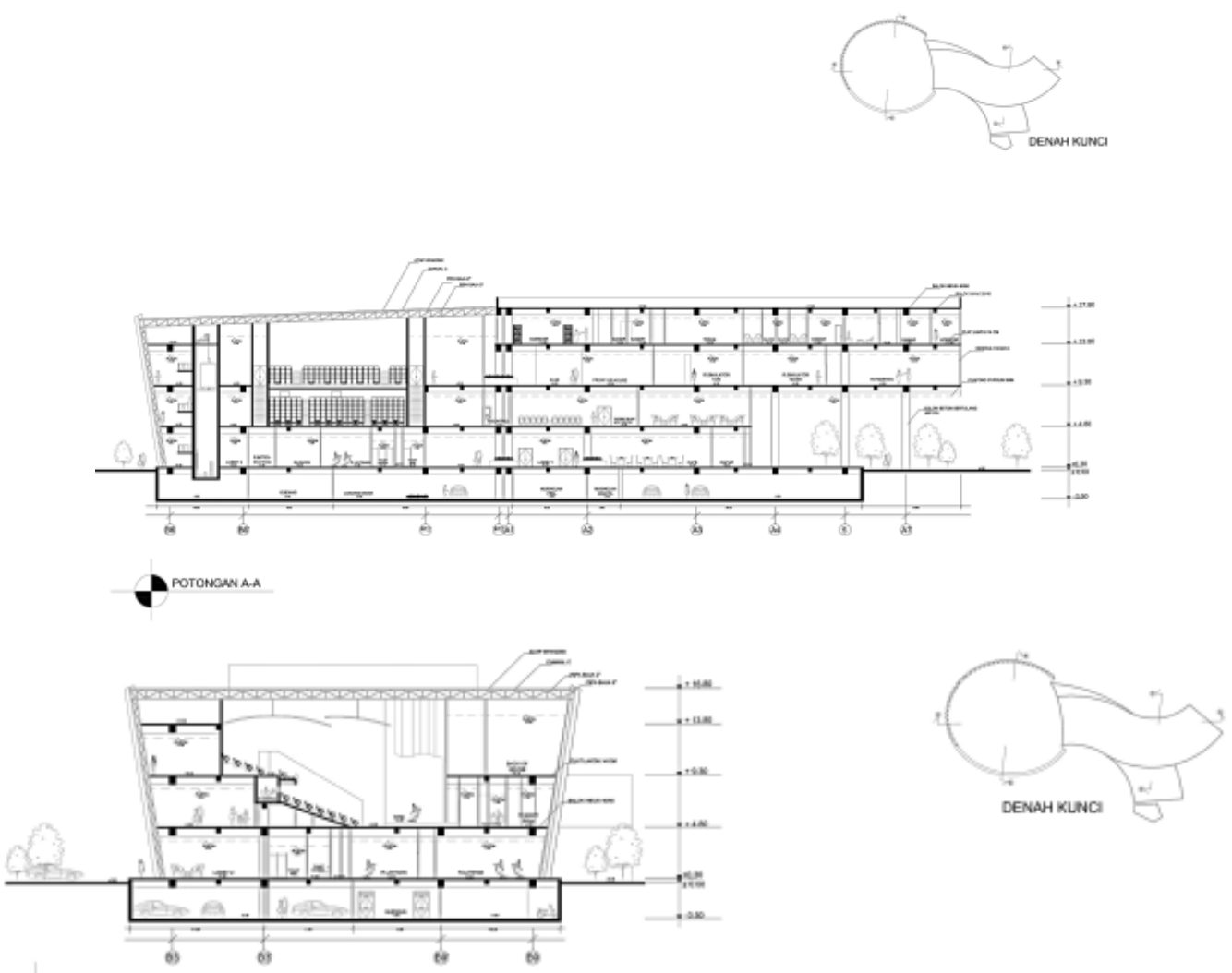

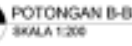

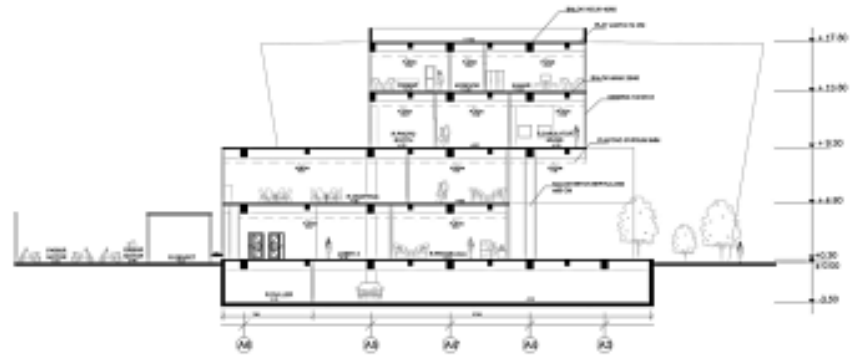

potongen c-c

Gambar 17. Potongan Bangunan

Sumber: Dokumen Pribadi 

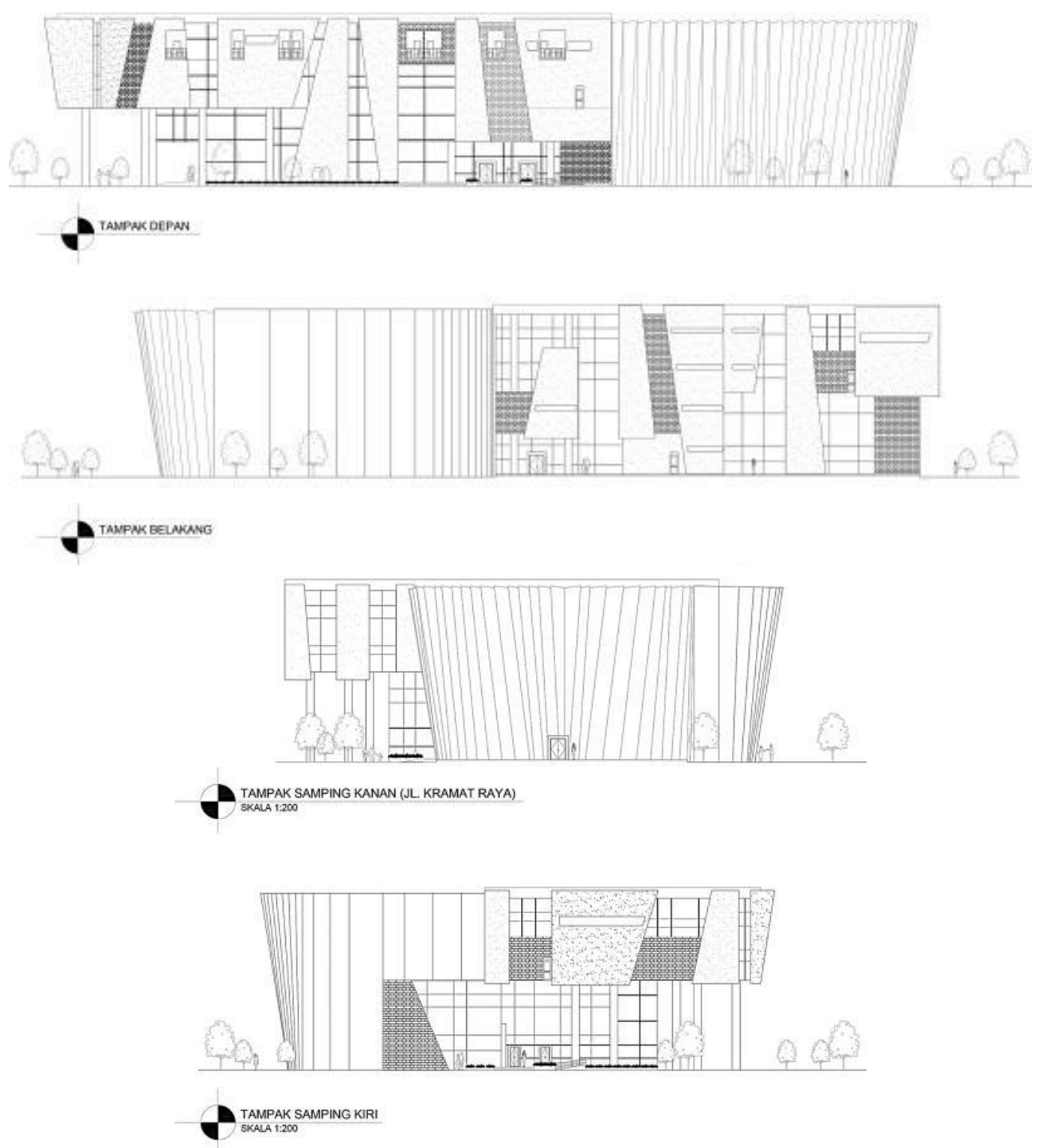

Gambar 18. Tampak Bangunan

Sumber: Dokumen Pribadi

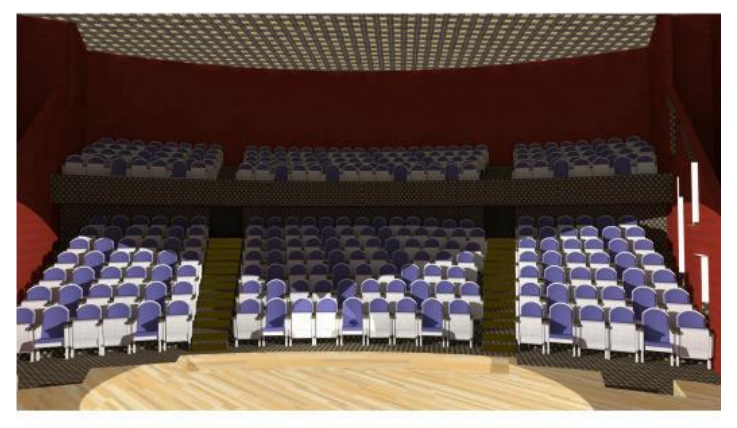

RUANG AUDITORIUM

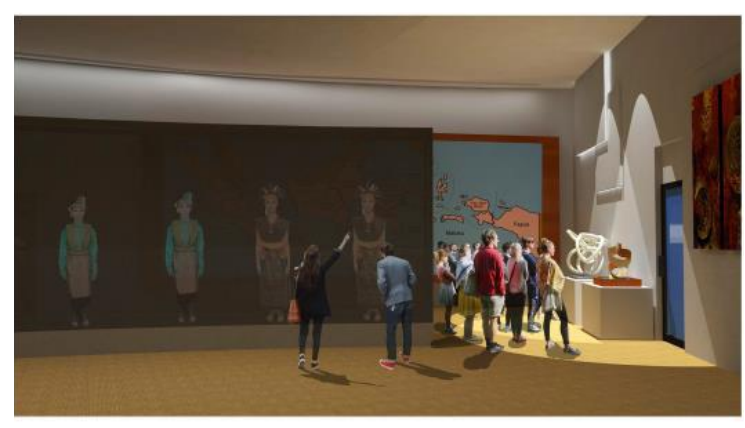

RUANG PAMERAN

Gambar 19. Interior Bangunan

Sumber: Dokumen Pribadi

\section{KESIMPULAN DAN SARAN}

\section{Kesimpulan}

Keberadaan Pagelaran Seni Tari Indonesia ini dapat meningkatkan fungsi Kawasan Senen sebagai kawasan seniman dan menambahkan ikon baru di kawasan Senen. Lokasi proyek 
berada di Jl. Kramat Bunder tepatnya berada di biosop tua Grand Theater yang kini sudah tidak beroprasi lagi. Pagelaran Seni Tari Indonesia merupakan bangunan yang dapat menampung 300 penonton serta bangunan yang menampilkan kebudayaan Indonesia terutama seni tari tradisional itu sendiri serta dilengkapi dengan pengetahuan mengenai sejarah tari tradisional dengan cara yang berbeda, memanfaatkan teknoloi yang ada. Pagelaran Seni Tari Indonesia berfungsi sebagai ruang publik yang dapat menampung kegiatan kesenian namun tetap bersifat terbuka bagi masyarakat luas.

Bentuk pemanfaatan pagelaran seni tari Indonesia di Senen, tidak hanya diaplikasikan dalam kegiatan kesenian saja, adapun kegiatan lain yang diselenggarakan antara lain pameran baju adat tari dari 34 provinsi yang dilengkapi dengan sejarahnya, workshop, ruang simulator, VR room, ruang gaya, ruang photo booth, serta ruang intro duction yang menampilkan sejarah asal mula terciptanya sebuah tarian, dan terdapat ruang penginapan yang digunakan untuk para penari yang akan melaksanakan pertunjukan.

Dengan adanya Pagelaran Seni Tari Indonesia ini dapat membantu untuk menjaga, dan melestari seni tari tradisional yang telah diwariskan secara turun-temurun.

Saran

Seni tari tradisional adalah warisan budaya yang sudah ada berpuluh-pulu tahun lamanya. Yang diciptakan oleh nenek moyang kita, dalam kesenian tradisonal banyak pesan moral yang terkandung didalamnya yang menceriminkan kepribadian bangsa Indonesia, sehingga seni ini perlu di kembangkan dan ditunjukan kepada masyarakat luas khususnya remaja sebagai sarana rekreasi dan pembelajaran.

Dengan kemajuan jaman dan teknologi masa sekarang seharusnya kebudayaan tidak ditinggalkan, namun memanfaatkan teknologi sekarang untuk memperkenalkan kembali seni tari tradisional dengan tampilan yang lebih modern dan menarik kepada masyarakat Indonesia dan wisatawan mancanegara.

Dengan adanya Pagelaran Seni Tari Indonesia di Kawasan Senen, Jakarta Pusat akan dapat memberikan suatu ketertarikan masyarakat sekitar dan wisatawan mancanegara maupun wisatawan domestik untuk mengetahui sejarah seni tradisional Indonesia, dan melestarikannya.

\section{UCAPAN TERIMA KASIH}

Pada kesempatan ini penulis menyampaikan rasa terimakasih kepada Tuhan Yang Maha Esa karena berkat rahmat dan ridho Nya sehingga penulis dapat menyelesaikan tulisan ini. Diharapkan proyek ini dapat dikembangkan lebih lanjut sehingga bermanfaat bagi masyarakat Indonesia, khususnya seniman yang ada di Senen yang tidak memiliki wadah mengekpresikan dirinya. Penulis juga mengucapkan terima kasih kepada Ketua Jurusan Arsitektur Fakultas Teknik Universitas, Pembimbing Akademik penulis dan Koordinator Program Studio Perancangan Arsitektur 8 yang telah memberikan semangat kepada penulis sehingga penulis mampu menyelesaikan tulisan ini.

\section{REFERENSI}

Logbook Stupa 8.26 Architourism of the Metropolis

Specht, Jan. (2014). Architourism: Building for Urban Travel Destination, Gabler Verlag. HIm. 18 https://www.ukssays.com/essays/geography/characteristics-metropolitan-5724.php, diakses

12 Juli 2018.

https://jakarta.o.id/artikel/konten/167/kampung-senen, diakses 12 Juli 2018. 